\title{
Incidence rate of pathogen-specific clinical mastitis on conventional and organic Canadian dairy farms
}

\author{
L. J. Levison, ${ }^{*}$ E. K. Miller-Cushon,† A. L. Tucker, ${ }^{\star}$ R. Bergeron,‡ K. E. Leslie,§ H. W. Barkema,\# \\ and T. J. DeVries*1 \\ *Department of Animal Biosciences, University of Guelph, Guelph, ON, N1G 2W1, Canada \\ †Department of Animal Sciences, University of Florida, Gainesville 32611 \\ ‡Department of Animal Biosciences, University of Guelph, Alfred, ON, KOB 1A0, Canada \\ §Department of Population Medicine, University of Guelph, Guelph, ON, N1G 2W1, Canada \\ \#Department of Production Animal Health, Faculty of Veterinary Medicine, University of Calgary, Calgary, Alberta T2N 4N1, Canada
}

\section{ABSTRACT}

Mastitis is a common and costly production disease on dairy farms. In Canada, the incidence rate of clinical mastitis (IRCM) has been determined for conventionally managed dairy farms; however, no studies to date have assessed rates in organically managed systems. The objectives of this observational study were (1) to determine the producer-reported IRCM and predominant pathogen types on conventional and organic dairy farms in Southern Ontario, Canada, and (2) to evaluate the association of both mean overall IRCM and pathogen-specific IRCM with management system, housing type, and pasture access. Data from 59 dairy farms in Southern Ontario, Canada, distributed across conventional $(\mathrm{n}=41)$ and organic management $(\mathrm{n}=$ 18) systems, were collected from April 2011 to May 2012. In addition to management system, farms were categorized by housing method (loose or tie-stall) and pasture access for lactating cows. Participating producers identified and collected samples from 936 cases of clinical mastitis. The most frequently isolated mastitis pathogens were coagulase-negative staphylococci, $B a$ cillus spp., Streptococcus spp., Staphylococcus aureus, and Escherichia coli. The IRCM was higher on conventional farms than organic (23.7 vs. 13.2 cases per 100 cow-years) and was not associated with housing type (loose or tie-stall), pasture access, or herd-average milk yield. Bulk tank somatic cell count tended to be lower on conventional farms than organic (222,000 vs. 272,000 cells/mL). Pathogen-specific IRCM attributed to Staph. aureus, Bacillus spp., and E. coli was greater on conventional than organic farms, but was not associated with housing or any other factors. In conclusion, organic management was associated with reduced overall and pathogen-specific IRCM.

Received May 12, 2015.

Accepted October 14, 2015.

${ }^{1}$ Corresponding author: tdevries@uoguelph.ca
Key words: clinical mastitis, dairy cow, organic, pathogens

\section{INTRODUCTION}

Mastitis is the most common and costly production disease on dairy farms worldwide (Reyher et al., 2011), resulting in production losses (Auldist and Hubble, 1998), decreased milk quality (Barbano et al., 2006), and a negative effect on cow welfare by inciting pain, especially during episodes of severe clinical mastitis (Kemp et al., 2008; Siivonen et al., 2011; Leslie and Petersson-Wolfe, 2012). Whereas mastitis control can be difficult regardless of system type (organic or conventional) under which the farm is managed (Marley et al., 2010), mastitis management in organic herds poses a particular challenge because of the restrictions on antibiotic use (Marley et al., 2010). Producers must alter treatment strategies from conventional industry norms to comply with organic regulations (Ruegg, 2009). Further, low veterinary medicine inputs are important aims in organic livestock farming (Ivemeyer et al., 2011).

Some concerns have been expressed particularly regarding the welfare of cattle in organic systems (Vaarst et al., 2001) due to the restricted use of antibiotics and possible delay in treatment (Hovi et al., 2003; Marley et al., 2010). Recent studies have compared udder health and milk quality on organic and conventional herds in different regions. Studies conducted in the United States have reported that organic dairy herds have reduced incidence rate of clinical mastitis (IRCM; Richert et al., 2013), whereas the incidence rate of subclinical mastitis has been reported to be similar between organic and conventional farms (Mullen et al., 2013). Most studies have reported no consistent difference in the bulk tank SCC (BTSCC) of milk from organic and conventional farms (Fall et al., 2008; Cicconi-Hogan et al., 2013a; Stiglbauer at al., 2013), but some reports were found of higher SCC on organic farms (Nauta et al., 2006; Roesch et al., 2007). Whereas several recent studies 
have assessed IRCM on conventional and organic herds across regions in the United States (Mullen et al., 2013; Richert et al., 2013), studies on clinical mastitis rates and pathogens in Canadian dairies have not specifically included certified organic farms (Sargeant et al., 1998; McLaren et al., 2006; Olde Riekerink et al., 2008). The reported IRCM has been similar across conventional farms in Canadian studies, with reports of a 20 to $22 \%$ lactational incidence risk (Sargeant et al., 1998; McLaren et al., 2006) or 23 to 26 cases per 100 cow-years at risk (Olde Riekerink et al., 2008; Thompson-Crispi et al., 2013).

Standards for organic farming differ widely between different countries, and it is unclear whether comparative studies conducted in other regions are reflective of management-specific differences in Canada (Barkema et al., 2015). Comparing udder health between different management systems is further complicated by the variety of on-farm factors that also influence IRCM, including herd size (Hill et al., 2009), as well as cow cleanliness and housing style. For instance, herds housed in tie-stalls have been found to have higher IRCM than freestall-housed herds (Olde Riekerink et al., 2008; Richert et al., 2013). The risk of clinical mastitis also relates to pasture access, decreasing when cows have pasture access at night (Barkema et al., 1999) and with a specific rotation pattern of pasture use during the dry period (Green et al., 2007). High levels of milk production are also positively associated with IRCM (Barkema et al., 1999); rations that are higher in forage and lower in concentrate may result in lower milk production, as has been observed in organic farms (Sato et al., 2005; Hamilton et al., 2006). It is important to understand the effect of management strategies on herd IRCM in both conventional and organic herds, and it is likely that these factors will differ by region.

The objectives of this study were to determine the producer-reported overall and pathogen-specific IRCM on conventional and organic dairies in Southern Ontario, Canada, and to investigate the associations between IRCM and herd-level factors including management system, housing style, pasture access, BTSCC, and milk yield.

\section{MATERIALS AND METHODS}

\section{Herd Selection}

Mail-outs through CanWest DHI (Guelph, ON, Canada) were sent to 505 producers (both conventional and organic) in Southern Ontario. Focused mail-outs were also sent to 47 organic producers in the same region (some of these organic producers targeted by focused mail-outs may have also received mail-outs through CanWest DHI). An initial questionnaire in the mail-out was used to identify interested producers. The initial response rate was 19\%, and after willingness and eligibility to participate were confirmed, 59 herds were selected for participation.

Sample size (target of 60 herds) was determined through power analysis using the Power Analysis and Sample Size software program (PASS, Kaysville, UT; Hintze, 2008). The estimate of variation for the primary response variable, IRCM, was based on that previously reported (Olde Riekerink et al., 2008). An estimated sample size of 60 herds, with 20 organic and 40 conventional (split between those with and without pasture access), was determined to be sufficient to detect a difference of $30 \%$ in IRCM. All willing organic producers were enrolled (18 organic farms) and conventional farms were selected with an attempt to distribute farms between similar herd size strata compared with organic farms ( $<49$ cows, 50-79 cows, $\geq 80$ cows). Upon enrollment, other herd characteristics were recorded, including housing (loose housing or tie-stall) and pasture access (Table 1). Pasture access was considered present when lactating cows had regular access (as reported by the producer; usually daily) to a grass-based field with the opportunity to graze when seasonally appropriate (in spring and summer months). Freestall and bedded pack barns were grouped together into the category of loose housing. All participating conventional herds consisted predominantly of Holstein-Friesian cows; occasionally a small number of other breeds (e.g., Jersey, Ayrshire) were present in these herds. Organic herds had greater breed variability of milking cows. One organic farm milked strictly Brown Swiss, and another Jersey cattle. The other 16 organic herds were composed of primarily Holstein-Friesian cows, with a mixture of other breeds included (e.g., Ayrshire, Brown Swiss, Jersey, Montbéliarde) or crossbred animals. Herds participated in the study between March 2011 and May 2012. All herds remained enrolled for the entire study duration.

\section{Sampling}

Participating producers were asked to aseptically collect milk samples from every quarter demonstrating signs of clinical mastitis, before treatment was given. Clinical mastitis was defined to the producers as any change to the normal appearance of milk, which could include flakes, clots, blood, or a watery consistency (Olde Riekerink et al., 2008); however, protocol for inspecting abnormal milk (e.g., use of fore-stripping) was not dictated to producers. Sample collection techniques were discussed and demonstrated with each producer during an initial farm visit conducted by study personnel (the same person visited each farm), and a written 
protocol was provided along with all sampling materials. Producers were asked to record the date the sample was taken, cow identification, and identify quarter(s) sampled. In addition, the producer was asked to add a mastitis severity score (MSS; Sargeant et al., 1998), indicating severity of infection: MSS 1 (quarter normal and abnormal milk), MSS 2 (quarter swollen and abnormal milk), or MSS 3 (quarter swollen, abnormal milk and cow systemically ill). The samples were stored in a freezer on-farm and were collected every $8 \mathrm{wk}$ for all farms. Samples were compiled into batches and shipped overnight on ice to the Faculty of Veterinary Medicine of the University of Calgary (Calgary, AB, Canada) for bacteriological culture.

Cow and herd specific information (e.g., cow age, calving date, lactation number, removal from herd date and reason, BTSCC, and monthly milk production) were obtained from CanWest DHI (Guelph, ON, Canada) and the Dairy Farmers of Ontario (Mississauga, ON, Canada). CanWest DHI information was not available for 3 organic herds because they were not enrolled with that organization, so information was obtained directly from the producer records.

\section{Laboratory Analysis}

National Mastitis Council standards (Hogan et al., 1999) were used when performing the bacteriological cultures of all milk samples. An aliquot of $0.01 \mathrm{~mL}$ of a sample was plated on Columbia Agar with 5\% sheep blood (BD, Mississauga, ON, Canada; catalog no. 221263) and incubated for $48 \mathrm{~h}$ at $37^{\circ} \mathrm{C}$. Colonies were examined for hemolytic activity and the number of colony-forming units for each sample was counted. Gram staining was performed. Gram-positive bacterial cells were further characterized by the catalase test (catalase test reagent, PML Microbiologicals, Wilsonville, OR; catalog no. R6452-30 mL). Gram-positive cocci, which were catalase-positive, DNase-positive (DNase Test Agar with Methyl Green, BD, catalog no. 222020), and tube coagulase-positive (Coagulase Plasma $25 \mathrm{~mL}$, Remel, Lenexa, KS; catalog no. R21052), were identified as Staphylococcus aureus. Gram-positive cocci, which were catalase-negative, were identified as Streptococcus spp. These isolates then underwent species differentiation tests including growth of isolates on Bile Esculin Agar Slants (BD, catalog no. 221409) in Salt Growth Media (BD, catalog no. 297189), and in Phenol Red Media containing inulin and raffinose (Hardy Diagnostics, Santa Maria, CA; catalog no. Y308 and Y 312). Detection of hydrolysis of sodium hippurate was also performed (ninhydrin reagent, Remel, catalog no. R21238; sodium hippurate hydrate, Sigma, catalog no. H9380-25G). Streptococcus spp. groups B, C, and G were identified using the Streptococcal-Select Grouping Kit (Inter Medico, Markham, ON, Canada; catalog no. PL.041C). Gram-positive rod-shaped bacteria, which were catalase-negative, were identified as Trueperella pyogenes. Gram-positive rod-shaped bacteria, with a catalase-positive test were identified as Bacillus spp. or Corynebacterium spp. depending on colony appearance.

Gram-negative rod-shaped bacteria first underwent an oxidase test (BD, BBL DrySlide Oxidase, catalog no. 231746). Oxidase-positive bacteria were identi-

Table 1. Distribution of participating herds and incidence rate of clinical mastitis $(\text { IRCM })^{1}$

\begin{tabular}{|c|c|c|c|c|c|c|c|}
\hline Farm description & $\begin{array}{c}\text { Number of } \\
\text { participating } \\
\text { herds }\end{array}$ & $\begin{array}{c}\text { Number of } \\
\text { quarter clinical } \\
\text { mastitis samples }\end{array}$ & $\begin{array}{l}\text { Total cow- } \\
\text { years at risk }\end{array}$ & $\begin{array}{l}\text { Mean } \\
\text { IRCM }^{2}\end{array}$ & $\begin{array}{l}95 \% \text { CI } \\
\text { for IRCM }\end{array}$ & $\begin{array}{l}\text { Geometric } \\
\text { mean } \\
\text { BTSCC }^{3}\end{array}$ & $\begin{array}{l}\text { Milk yield } \\
\text { (kg/cow } \\
\text { per d) }\end{array}$ \\
\hline \multicolumn{8}{|l|}{ Organic } \\
\hline Tie-stall & 7 & 71 & 278 & 15.3 & $11.9-18.6$ & 218 & 24.1 \\
\hline \multicolumn{8}{|l|}{ Conventional } \\
\hline Loose, pasture & 3 & 73 & 305 & 22.8 & $10.3-54.4$ & 376 & 29.0 \\
\hline Tie-stall, no pasture & 19 & 305 & 1,214 & 23.0 & $15.5-30.5$ & 226 & 33.8 \\
\hline \multicolumn{8}{|l|}{ Total by management } \\
\hline Organic & 18 & 197 & 1,282 & 13.2 & $9.0-17.3$ & 271 & 21.5 \\
\hline Conventional & 41 & 739 & 2,987 & 23.7 & $18.7-28.8$ & 222 & 32.3 \\
\hline \multicolumn{8}{|l|}{ Total by housing } \\
\hline Loose & 24 & 463 & 2,392 & 16.8 & $11.5-22.1$ & 232 & 26.8 \\
\hline Tie-stall & 35 & 473 & 1,879 & 23.7 & $18.0-29.5$ & 241 & 31.2 \\
\hline
\end{tabular}

${ }^{1}$ Calculated on a 365 -d basis for each cow.

${ }^{2}$ Incidence rate of clinical mastitis per 100 cow-years at risk.

${ }^{3}$ Bulk tank SCC $(\times 1,000$ cells $/ \mathrm{mL})$.

${ }^{4}$ Loose $=$ freestall or bedded-pack housing. 
fied as other gram-negative rods or Pseudomonas spp. depending on colony appearance. Oxidase-negative bacterial isolates went through further testing including growth on MacConkey II agar with MUG (BD, catalog no. 221938), Levine EMB agar (BD, catalog no. 221170), and inoculation onto Simmons Citrate Agar Slant (BD, catalog no. 221026), Urea Agar Slant (BD, catalog no. 221096), and Motility Test Medium (BD, catalog no. 221509). Additionally, an indole spot test was performed (indole spot test reagent, PML Microbiologicals, catalog no. R6510-30 mL). These tests were done to differentiate Escherichia coli, Klebsiella spp., and Enterobacter spp.

Counts $(\mathrm{cfu} / \mathrm{mL})$ of each bacterial species identified in a sample were used to diagnose that IMI was present. Criteria were used from Dohoo et al. (2011), who recommended considering a quarter positive at 100 $\mathrm{cfu} / \mathrm{mL}$ for all pathogens, except CNS for which 200 $\mathrm{cfu} / \mathrm{mL}$ was used. A sample was considered to be a mixed culture when 2 pathogens were present, and contaminated when 3 or more pathogens were identified, except when Staph. aureus or Streptococcus agalactiae were present (Olde Riekerink et al., 2008).

\section{Calculation and Statistical Analyses}

A cow was considered at risk for clinical mastitis during lactation and the dry period while the herd was enrolled in the study. The time at risk started when either the farm was first visited by researchers, the day the lactating cow entered the herd, the day of calving, or $14 \mathrm{~d}$ after the last mastitis episode identified by the producer (Olde Riekerink et al., 2008). The risk period ended when either the cow had clinical mastitis, died, or was culled (Olde Riekerink et al., 2008). For cows with recurrent clinical mastitis in the same quarter, a case was considered new and therefore included in the analysis when $\geq 14 \mathrm{~d}$ occurred between episodes. The IRCM was expressed as the number of quarter cases per 100 cow-years at risk.

Bulk tank SCC was determined monthly by the Dairy Farmers of Ontario (Mississauga, Ontario, Canada). Geometric mean BTSCC determined for each herd was used to categorize herds: low $(<150,000$ cells/ $\mathrm{mL})$, medium $(150,000$ to 250,000 cells $/ \mathrm{mL})$, and high (>250,000 cells/mL; Olde Riekerink et al., 2008). Due to a small number of farms in the lower 2 categories, herds were classified as low and medium $(<250,000$ cells $/ \mathrm{mL})$ or high $(>250,000)$ for analysis, and the proportion of organic and conventional farms in each category was analyzed in a chi-squared test.

All data were summarized by farm, and farm was considered the experimental unit. Prior to analyses, all data were screened for normality (SAS Institute Inc., Cary, NC). Overall IRCM and pathogen-specific IRCM were square root-transformed and BTSCC was natural log-transformed. Associations between IRCM, producer-reported MSS, and herd-level variables (management system, housing type, farm size category ( $<49$ cows, 50-79 cows, $\geq 80$ cows), average daily milk yield, pasture use, mean BTSCC, and BTSCC category) were analyzed with multivariable linear mixed regression models using the MIXED procedure of SAS (SAS Institute Inc.). Because the predominant breed was Holstein-Friesian on 57 of the 59 farms enrolled, it was not possible to include predominant breed in the statistical models. All models included management system, housing type, and farm size category. Unconditional associations between IRCM and other predictor variables (pasture use, BTSCC category, and average daily milk yield) were examined, and any independent variable liberally associated with the outcome variable $(P<0.25)$ was considered for inclusion in the final model. Spearman correlation coefficients were calculated for all predictor variables that were considered for inclusion in the multivariable models to detect issues of collinearity. Consequently, if the correlation coefficient was greater than $|0.8|$, the variable that made the most biological sense was used. For the multivariable model, effects were considered significant at $P \leq 0.05$ and tendencies at $0.05<P \leq 0.10$. Manual backward elimination of nonsignificant, and nontrending effects was used to construct the final multivariable models. Plausible 2-way interactions were examined and retained if $P \leq 0.10$. Only those results retained in the final multivariable models are presented. For analysis of the pathogen-specific IRCM, a relatively small number of cases was found for some pathogens in each housing type category. Consequently, low statistical power was present to detect differences, thus limiting the extent of this analysis. As such, pathogen-specific IRCM were analyzed in a model including only the design variable of management system.

\section{RESULTS}

Of the farms participating in the study, $70 \%$ were conventional and 30\% were organic (Table 1). Herds with pasture access for their lactating animals made up $51 \%$ of participating farms ( $29 \%$ of conventional farms and $100 \%$ of organic farms). Loose housing, rather than tie-stalls, for lactating cows was used on $41 \%$ of farms (32\% of conventional dairy farms and $61 \%$ of organic dairies). A total of 5,395 lactating cows were present in the 59 participating herds. Average milking herd size was 65 , ranging from 18 to 220 cows. Average milking 
herd size was 67 cows for organic farms (range 18 to 220 ) and 64 cows for conventional farms (range 22 to $220)$.

Overall mean and median herd IRCM were 20.9 and 16.4 cases per 100 cow-years at risk, respectively. Mean IRCM was 13.2 cases per 100 cow-years on organic farms and 23.7 cases per 100 cow-years on conventional farms (Table 1), and ranged from 0.0 to 55.6 (Figure 1). Mean daily production during the study period was $32.3 \mathrm{~kg} / \mathrm{d}$ for conventional farms and $21.5 \mathrm{~kg} / \mathrm{d}$ for organic herds (Table 1). Geometric mean BTSCC tended $(P=0.07)$ to be lower on conventional farms $(222,000 \pm 100,000$ cells $/ \mathrm{mL}$; mean $\pm \mathrm{SD}$ ) compared with organic farms $(272,000 \pm 87,000$ cells $/ \mathrm{mL}$; Table 1$)$. Categorization of herds based on yearly geometric mean BTSCC resulted in 34 farms ( 7 organic farms and 26 conventional farms) in the low and medium category $(<250,000$ cells $/ \mathrm{mL})$, and 26 farms (11 organic farms and 15 conventional farms) in the high category $(>250,000$ cells $/ \mathrm{mL})$. The proportion of conventional and organic farms in each category tended to differ $(P=0.08)$.

During the study period, 936 clinical mastitis quarter samples were submitted from 743 cows. Clinical mastitis samples were submitted from $58(98 \%)$ of participating farms. Coagulase-negative staphylococci were the most frequently isolated clinical mastitis pathogens, followed by Bacillus spp., Streptococcus spp., and Staph. aureus (Table 2). No growth was detected in $22.4 \%$ of samples cultured $(22.3 \%$ of samples from conventional farms and $23.1 \%$ of samples from organic farms) and sample contamination rate was $6.4 \%$ (6.9\% of samples from conventional farms and $4.6 \%$ of samples from organic farms). The majority of clinical mastitis samples yielded a single culture. However, 196 samples (20.9\%) were mixed, with 2 pathogens isolated. Of the 743 cows that contributed clinical mastitis samples, 26 cows had repeat samples taken from the same quarter with the same infection during the study (22 from conventional farms and 4 from organic farms). Of these repeat cases, 8 were from Staph. aureus, 7 were CNS, 5 were Bacillus spp., 2 were Streptococcus spp., and one repeat case was found of yeast, E. coli, and Streptococcus uberis. Median interval between collecting repeat samples was $47 \mathrm{~d}$ (range 18 to $202 \mathrm{~d}$ ).

Mastitis severity was recorded for $90.7 \%$ of submitted clinical samples. Abnormal milk as the only indicator of mastitis (MSS 1) was observed in $57.0 \%$ of cases (56.9\% of cases on conventional farms, and $57.3 \%$ of cases on organic farms), abnormal milk with physical changes evident in the quarter (MSS 2) was observed in $36.2 \%$ of cases $(37.0 \%$ of cases on conventional farms, and $32.7 \%$ of cases on organic farms), and signs of abnormal milk, swollen quarter, and systemic illness (MSS 3$)$ were observed in $6.8 \%$ of cases $(6.0 \%$ of cases

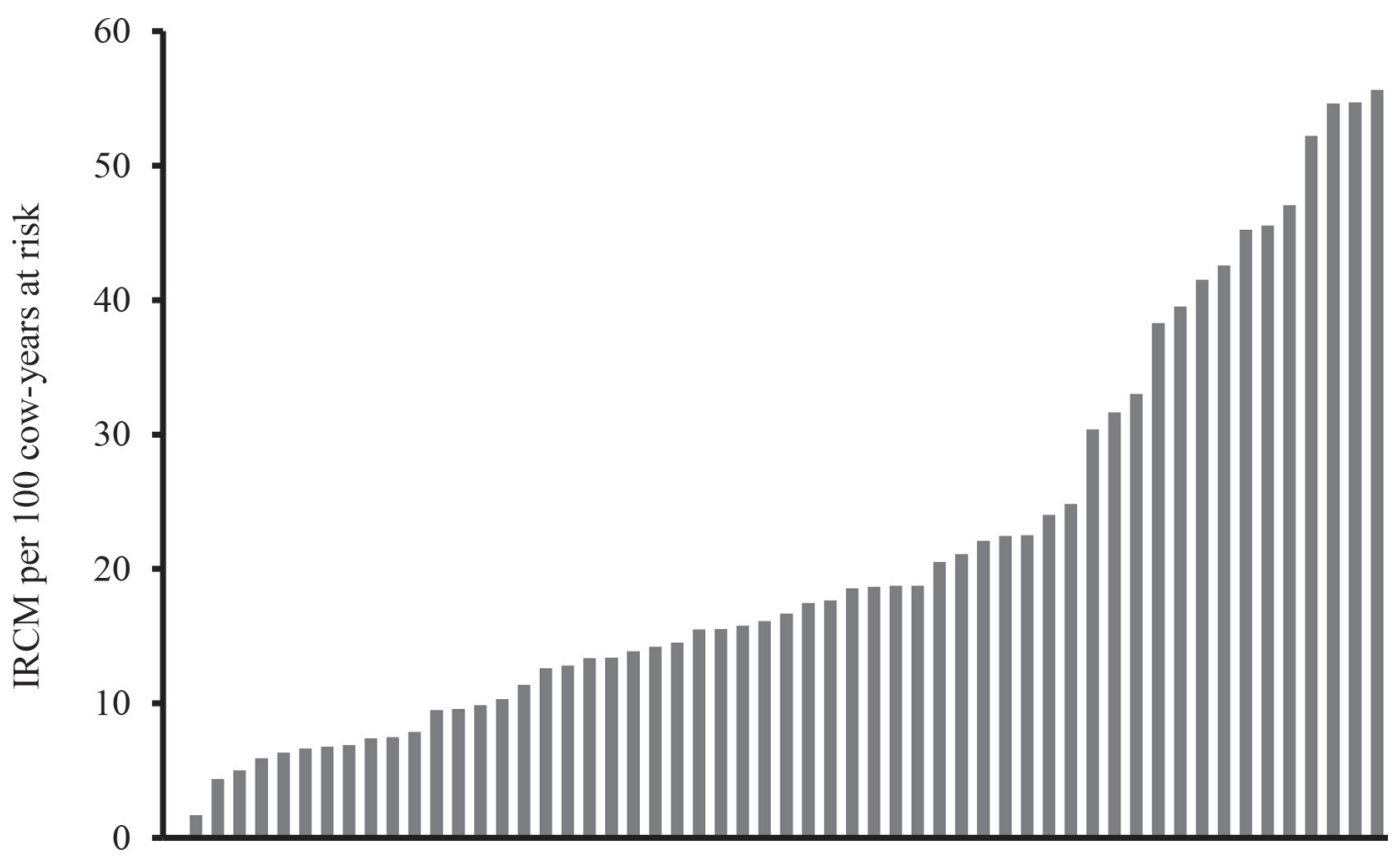

Herd

Figure 1. Incidence rate of clinical mastitis (IRCM) in the 59 herds that participated in the study. 
on conventional farms and $9.9 \%$ of cases on organic farms). Severity of reported mastitis cases did not differ between organic and conventional farms (mean MSS score of 1.6 and 1.5 for conventional and organic farms, respectively; $\mathrm{SE}=0.09, P=0.35)$.

No unconditional association was found between pasture access and IRCM, so herds with and without pasture access were pooled within management style and housing type for analysis. The final model for assessing overall IRCM included design variables (management and housing type), but no other predictor variables (including average daily milk yield, BTSCC, and herd size) were unconditionally associated. Overall IRCM was greater on conventional farms than organic farms (Table 3), but was not associated with housing (loose or tie-stall), herd size, or average daily milk yield.

The pathogen-specific IRCM for the 5 most commonly isolated pathogens (Staph. aureus, Bacillus spp., E. coli, CNS, and Streptococcus spp.) is reported in Table 4. The pathogen-specific IRCM for Staph. aureus, Bacillus spp., and E. coli was greater on conventional than organic farms.

\section{DISCUSSION}

On-farm clinical mastitis research to date has used herd health records, producer sampling, retrospective producer recall, and national health recording systems to identify IRCM (Barkema et al., 1998; Bartlett et al., 2001; Sato et al., 2005). The current study relied solely on producer submitted clinical mastitis samples, asking producers to sample every quarter case of self-identified clinical mastitis before treatment. A clear definition of clinical mastitis was stated and reviewed with all producers at the start of the study in an attempt to standardize case identification. Strategies used to encourage producer collection included farm visits, phone calls, or both at least once every $8 \mathrm{wk}$, as well as reporting milk sample bacteriology results to the producer as frequently as possible throughout the study period. Producer detection bias was possible, as it has been suggested that producers may be more likely to sample cows with severe clinical mastitis (Olde Riekerink et al., 2008). However, in the present study, $57 \%$ of cases were identified as MSS 1 (abnormal milk as the only indicator of

Table 2. Distribution of mastitis pathogens isolated from milk samples taken from cows with clinical mastitis

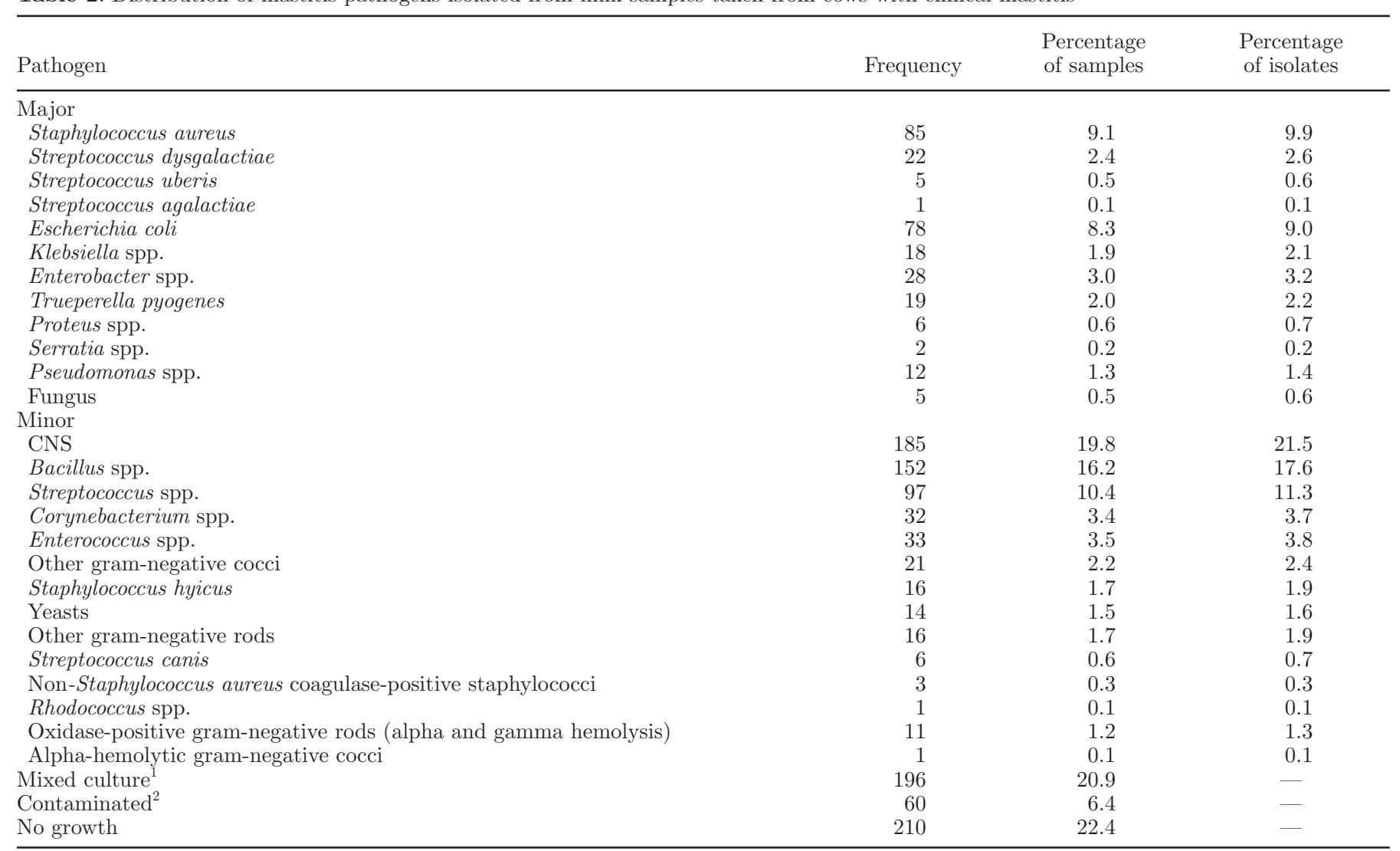

${ }^{1}$ Sample with 2 pathogens identified on culture. Included in isolate frequencies.

${ }^{2}$ Sample with 3 or more pathogens identified on culture. Included in isolate frequencies if contaminated with Staphylococcus aureus present. 
Table 3. Final general linear model for factors associated with the incidence rate of producer-identified clinical mastitis (IRCM) $)^{1}$

\begin{tabular}{|c|c|c|c|}
\hline \multirow[b]{2}{*}{ Variable } & \multicolumn{3}{|c|}{ IRCM } \\
\hline & $\beta^{3}$ & $\mathrm{SE}$ & $P$-value \\
\hline Intercept & 3.9 & 1.1 & $<0.001$ \\
\hline Management system & & & 0.026 \\
\hline Conventional & 1.3 & 0.57 & \\
\hline Organic & $\operatorname{Ref}^{4}$ & - & \\
\hline \multicolumn{4}{|l|}{ Housing } \\
\hline Loose & -0.26 & 0.56 & 0.65 \\
\hline Tie-stall & Ref & - & \\
\hline \multicolumn{4}{|l|}{ Herd size } \\
\hline$<49$ cows & -0.07 & 0.9 & 0.94 \\
\hline$>49,<79$ cows & -0.2 & 0.7 & 0.79 \\
\hline$\geq 80$ cows & Ref & - & \\
\hline Milk yield (kg/cow per d) & $-0.1 \times 10^{-4}$ & $0.1 \times 10^{-4}$ & 0.33 \\
\hline
\end{tabular}

mastitis), suggesting that a bias was not present toward sampling cows with severe clinical mastitis. A similar distribution of mastitis severity scores (49 to $75 \%$ of cases classified as MSS 1) was reported in a range of studies reviewed by Ruegg (2012). It is important to note that the protocol for identifying abnormal milk was not dictated by the research staff and may have differed between farms. The use of fore-stripping in the milking routine has been shown to be associated with the rate of farmer-identified clinical mastitis (Richert et al., 2013). However, recent surveys of farms in the United States suggest that no bias exists between organic and conventional farms regarding the prevalence of fore-stripping in the milking routine (Richert et al., 2013; Mullen et al., 2013). Further, in the present study, the distribution of severity of reported mastitis cases was similar between organic and conventional farms, suggesting that no trend was present toward overlooking cases where abnormal milk was the only indicator of mastitis on either organic or conventional farms.

Table 4. Incidence rate of clinical mastitis ${ }^{1}$ and (number of farms with cases) for most commonly identified pathogens within management system

\begin{tabular}{lcl}
\hline Item & Conventional & Organic \\
\hline CNS & $5.6(31)$ & $2.7(13)$ \\
Bacillus spp. & $4.2(21)^{\mathrm{a}}$ & $1.6(6)^{\mathrm{b}}$ \\
Streptococcus spp. & $4.0(25)$ & $3.7(9)$ \\
Staphylococcus aureus & $3.7(27)^{\mathrm{a}}$ & $2.4(11)^{\mathrm{b}}$ \\
Escherichia coli & $3.6(26)^{\mathrm{a}}$ & $2.2(7)^{\mathrm{b}}$ \\
No growth & $6.6(39)$ & $4.8(14)$ \\
\hline
\end{tabular}

\footnotetext{
${ }^{\mathrm{a}, \mathrm{b}}$ Values within rows with different superscript letters are significantly different $(P<0.05)$.

${ }^{1}$ Per 100 cow-years at risk.
}

The contamination rate of clinical mastitis samples was lower in this study than previous research (Sargeant et al., 1998; Olde Riekerink et al., 2008), suggesting that farmers collecting samples generally performed proper sampling techniques. However, the percentage of samples with mixed cultures (2 organisms present) was greater than some previous findings (Olde Riekerink et al., 2008; Verbeke et al., 2014), although Barkema et al. (1998) reported a similar frequency of mixed cultures. No growth was detected in $22 \%$ of samples, which is in the range of previous findings (e.g., 44\%, Olde Riekerink et al., 2008; 18\%, Sargeant et al., 1998; 20\%, Verbeke et al., 2014). Negative cultures could have resulted from the freezing of milk samples (Schukken et al., 1989), spontaneous bacterial cure, the presence of too few bacteria for culture (Zorah et al., 1993), or from samples that truly did not contain a pathogen, which could be related to producer case identification.

The IRCM determined in this study for conventional farms (median 18.8, mean 26.3 cases per 100 cow-years) was similar to that of other values reported from Canadian studies (e.g., 26.3 cases per 100 cowyears; Thompson-Crispi et al., 2013; 23.0 cases per 100 cow-years, Olde Riekerink et al., 2008; and 21.8 per 100 lactations; McLaren et al., 2006). As previously reported (Barkema et al., 1998; Sargeant et al., 1998; Olde Riekerink et al., 2008), considerable variation in IRCM among herds was observed.

Although several studies have investigated the effect of organic management on IRCM outside of Canada, Ruegg (2009) cautioned against comparison of studies from different countries, as the organic standards producers are required to maintain differ widely. Research directly comparing clinical and subclinical mastitis in- 
cidence in organic and conventional managed herds has yielded varying results. Many studies have noted no difference in SCC between organic and conventional farms (Fall et al., 2008; Cicconi-Hogan et al., 2013a; Stiglbauer at al., 2013), although some have reported higher SCC on organic farms (Nauta et al., 2006; Roesch et al., 2007), as seen in the present study. Similar to the present results, several recent studies have reported reduced IRCM in organic systems (Hamilton et al., 2006; Richert et al., 2013). Organic systems have been associated with lower milk production, as noted in this study, and high production has been associated with greater mastitis incidence (Schukken et al., 1990; Gröhn et al., 1995). However, herd-level milk production was not associated with IRCM in the present study. Nutrition may contribute to differences in IRCM. Canadian organic dairy producers are specifically required to have at least $60 \%$ of DM in daily rations consist of hay, fresh/dried fodder or silage (National Standards of Canada, 2011). Nyman et al. (2007) found that lower levels of concentrates were fed in herds with low veterinary-treated IRCM. As well, organic producers have suggested that the reduced production stress on organic cows may result in those animals maintaining higher immune function (Sato et al., 2005). It must be noted that a wide variety of mastitis risk factors is present that are not specific to organic production, including animal age, genetics, environmental conditions, and nutrition (Ruegg, 2009). In the present study, all conventional and organic herds were predominately Holstein-Friesian, whereas 2 of the organic farms milked Brown Swiss and Jersey cows, respectively. Although we were not able to enroll a sufficient number of farms to analyze the effects of predominate breed on IRCM, breed has potential to influence these outcomes. Further investigation is encouraged to assess the associations between a greater range of management and cow factors and IRCM on organic and conventional farms in Canada.

Surprisingly, CNS were the most frequently identified pathogens, found in $20 \%$ of samples, which is twice as frequent as in a previous Canadian study (11\%) that sampled clinical mastitis (Olde Riekerink et al., 2008). Similar to the present results, Reyher et al. (2012) reported that CNS was found in $20 \%$ of samples collected as part of the Canadian Bovine Mastitis Research Network's National Cohort of Dairy Farms longitudinal quarter milk sample study. However, in that study milk samples were not necessarily from cases of clinical mastitis (Reyher et al., 2012). Further, studies from other regions sampling subclinical cases of mastitis have reported CNS at rates similar to the current study (e.g., 20 to $28 \%$ of samples obtained at different stages of lactation from Swiss organic and conventional farms, Roesch et al., 2007; and 14 to $20 \%$ of samples from US organic and conventional farms, Mullen et al., 2013). It is not clear why CNS was identified in a higher frequency of clinical cases than in other recent studies, although regional differences may play a role. Although CNS have traditionally been considered minor mastitis pathogens (Schukken et al., 2009), some species of CNS have become recognized as a predominant pathogen causing mastitis (Taponen et al., 2006; Reyher et al., 2011).

Pathogen-specific IRCM attributed to Staph. aureus, Bacillus spp., and E. coli were greater on conventional farms compared with organic. Staphylococcus aureus is considered a major mastitis pathogen because of its effect on milk quality, production, and cow SCC (Keefe, 2012) and was the most frequently isolated contagious mastitis pathogen in this study (9.6\%). In contrast with the present results, Cicconi-Hogan et al. (2013b) reported Staph. aureus was more frequently identified in the bulk tank on US organic farms, compared with conventional. These authors suggested that this difference may be due to an increased rate of culling on conventional farms of cows with persistent IMI, as Staph. aureus often persists in the udder for extended periods of time (Reyher et al., 2012). However, Mullen et al. (2013) reported no difference in prevalence of Staph. aureus IMI between organic and conventional herds, suggesting that the effect of management on Staph. aureus likely depends on a variety of factors and may differ by region. In agreement with the present results, Cicconi-Hogan et al. (2013b) reported that a greater percentage of bulk tanks were positive for $E$. coli on US conventional farms compared with organic. Factors affecting susceptibility to E. coli in these farms are not clear; however, Cicconi-Hogan et al. (2013b) noted that coliform count on organic farms was associated with several management factors such as record keeping and years in the dairy industry. This suggests that the presence of $E$. coli is also likely to depend on several regional and management factors and may differ between organic and conventional farms. Further research is encouraged on a larger scale in Canada to identify other risk factors for pathogen-specific IRCM, as it is possible that housing, pasture access, and a wide range of other management factors may influence mastitis incidence to a degree that the present study lacked the power to detect.

\section{CONCLUSIONS}

Compared with conventional farms, organic farms had reduced mean herd producer-identified IRCM and pathogen-specific IRCM for Staph. aureus, Bacillus spp., and E. coli, but tended to have higher BTSCC. Housing system and access to pasture, herd size, and 
average milk yield for lactating cows were not associated with overall IRCM. These results suggest that reduced rates of producer-identified clinical mastitis for certain pathogens may be related to the organic management system. Further investigation is needed to identify specific management factors that affect IRCM on organic farms.

\section{ACKNOWLEDGMENTS}

The authors thank the producers for contributing their time and effort for this project. Tremendous thanks go to Uliana Kanevets and Amanda Reith of the University of Calgary (Calgary, AB, Canada) for performing the bacterial analysis on all clinical mastitis samples, Dairy Farmers of Ontario (Mississauga, ON, Canada) bulk milk tank graders for their help with bulk milk tank sampling, Karen Hand for her assistance with herd data retrieval, and the support of Ian Rumbles of CanWest DHI (Guelph, ON, Canada). Funding for this study was provided by the Organic Science Cluster, a part of the Canadian Agri-Science Clusters Initiative of Agriculture and Agri-Food Canada's Growing Forward Policy Framework.

\section{REFERENCES}

Auldist, M. J., and I. B. Hubble. 1998. Effects of mastitis on raw milk and dairy products. Aust. J. Dairy Technol. 53:28-36.

Barbano, D. M., Y. Ma, and M. V. Santos. 2006. Influence of raw milk quality on fluid milk shelf life. J. Dairy Sci. 89(Suppl. 1):E15-E19.

Barkema, H. W., Y. H. Schukken, T. J. G. M. Lam, M. L. Beiboer, G. Benedictus, and A. Brand. 1999. Management practices associated with the incidence rate of clinical mastitis. J. Dairy Sci. 82:1643-1654.

Barkema, H. W., Y. H. Schukken, T. J. G. M. Lam, M. L. Beiboer, H. Wilmink, G. Benedictus, and A. Brand. 1998. Incidence of clinical mastitis in dairy herds grouped in three categories by bulk milk somatic cell counts. J. Dairy Sci. 81:411-419.

Barkema, H. W., M. A. G. von Keyserlingk, J. P. Kastelic, T. J. G. M. Lam, C. Luby, J.-P. Roy, S. J. LeBlanc, G. P. Keefe, and D. F. Kelton. 2015. Invited review: Changes in the dairy industry affecting dairy health and welfare. J. Dairy Sci. 98:7426-7445. http:// dx.doi.org/10.3168/jds.2015-9377.

Bartlett, P. C., J. F. Agger, H. Houe, and L. G. Lawson. 2001. Incidence of clinical mastitis in Danish dairy cattle and screening for non-reporting in a passively collected national surveillance system. Prev. Vet. Med. 48:73-83.

Cicconi-Hogan, K. M., M. Gamroth, R. Richert, P. L. Ruegg, K. E. Stiglbauer, and Y. H. Schukken. 2013a. Associations of risk factors with somatic cell count in bulk tank milk on organic and conventional dairy farms in the United States. J. Dairy Sci. 96:3689-3702.

Cicconi-Hogan, K. M., M. Gamroth, R. Richert, P. L. Ruegg, K. E. Stiglbauer, and Y. H. Schukken. 2013b. Risk factors associated with bulk tank standard plate count, bulk tank coliform count, and the presence of Staphylococcus aureus on organic and conventional dairy farms in the United States. J. Dairy Sci. 96:7578-7590.

Dohoo, I. R., J. Smith, S. Andersen, D. F. Kelton, and S. Godden. 2011. Diagnosing intramammary infections: Evaluation of definitions based on a single milk sample. J. Dairy Sci. 94:250-261.

Fall, N., U. Emanuelson, K. Martinsson, and S. Jonsson. 2008. Udder health at a Swedish research farm with both organic and conventional dairy cow management. Prev. Vet. Med. 83:186-195.
Green, M. J., A. J. Bradley, G. F. Medley, and W. J. Browne. 2007. Cow, farm, and management factors during the dry period that determine the rate of clinical mastitis after calving. J. Dairy Sci. 90:3764-3776.

Gröhn, Y. T., S. W. Eicker, and J. A. Hertl. 1995. Association between previous 305-day milk yield and disease in New York State dairy cows. J. Dairy Sci. 78:1693-1702.

Hamilton, C., U. Emanuelson, K. Forslund, I. Hansson, and T. Ekman. 2006. Mastitis and related management factors in certified organic dairy herds in Sweden. Acta Vet. Scand. 48:11-17.

Hill, A. E. A. L. Green, B. A. Wagner, and D. A. Dargatz. 2009. Relationship between herd size and annual prevalence of and primary antimicrobial treatments for common diseases on dairy operations in the United States. Prev. Vet. Med. 88:264-277.

Hintze, J. 2008. PASS 2008. NCSS, LLC. Kaysville, UT. Accessed Dec. 8, 2010. www.ncss.com

Hogan, J. S., R. N. Gonzalez, R. J. Harmon, S. C. Nickerson, S. P. Oliver, J. W. Pankey, and K. L. Smith. 1999. Laboratory Handbook on Bovine Mastitis. Rev. ed. National Mastitis Council Inc., Madison, WI.

Hovi, M., A. Sundrum, and S. M. Thamsborg. 2003. Animal health and welfare in organic livestock production in Europe: Current state and future challenges. Livest. Prod. Sci. 80:41-53.

Ivemeyer, S., U. Knierim, and S. Waiblinger. 2011. Effect of humananimal relationship and management on udder health in Swiss dairy herds. J. Dairy Sci. 94:5890-5902.

Keefe, G. 2012. Update on control of Staphylococcus aureus and Streptococcus agalactiae for management of mastitis. Vet. Clin. North Am. Food Anim. Pract. 28:203-216.

Kemp, M. H., A. M. Nolan, P. J. Cripps, and J. L. Fitzpatrick. 2008 Animal-based measurements of the severity of mastitis in dairy cows. Vet. Rec. 163:175-179.

Leslie, K. E., and C. S. Petersson-Wolfe. 2012. Assessment and management of pain in dairy cows with clinical mastitis. Vet. Clin. North Am. Food Anim. Pract. 28:289-305.

Marley, C. L., R. F. Weller, M. Neale, D. C. J. Main, S. Roderick, and R. Keatinge. 2010. Aligning health and welfare principles and practice in organic dairy systems: A review. Animal 4:259-271.

McLaren, C. J., K. D. Lissemore, T. F. Duffield, K. E. Leslie, D. F. Kelton, and B. Grexton. 2006. The relationship between herd level disease incidence and a return over feed index in Ontario dairy herds. Can. Vet. J. 47:767-773.

Mullen, K. A. E., L. G. Sparks, R. L. Lyman, S. P. Washburn, and K. L. Anderson. 2013. Comparisons of milk quality on North Carolina organic and conventional dairies. J. Dairy Sci. 96:6753-6762.

National Standard of Canada. 2011. Organic Production SystemsGeneral Principles and Management Standards. Canadian General Standards Board, Gatineau, ON.

Nauta, W. J., T. Baars, and H. Bovenhuis. 2006. Converting to organic dairy farming: Consequences for production, somatic cell scores and calving interval of first parity Holstein cows. Livest. Sci. 99:185-195.

Nyman, A. K., T. Ekman, U. Emanuelson, A. H. Gustafsson, K. Holtenius, K. Persson Waller, and C. Hallen Sandgren. 2007. Risk factors associated with the incidence of veterinary-treated clinical mastitis in Swedish dairy herds with a high milk yield and a low prevalence of subclinical mastitis. Prev. Vet. Med. 78:142-160.

Olde Riekerink, R. G. M., H. W. Barkema, D. F. Kelton, and D. T. Scholl. 2008. Incidence rate of clinical mastitis on Canadian dairy farms. J. Dairy Sci. 91:1366-1377.

Reyher, K. K., I. R. Dohoo, D. T. Scholl, and G. P. Keefe. 2012. Evaluation of minor pathogen intramammary infection, susceptibility parameters, and somatic cell counts on the development of new intramammary infections with major mastitis pathogens. J. Dairy Sci. 95:3766-3780.

Reyher, K. K., S. Dufour, H. W. Barkema, L. Des Coteaux, T. J. DeVries, I. R. Dohoo, G. P. Keefe, J. P. Roy, and D. T. Scholl 2011. The national cohort of dairy farms - A data collection platform for mastitis research in Canada. J. Dairy Sci. 94:1616-1626.

Richert, R. M., K. M. Cicconi, M. J. Gamroth, Y. H. Schukken, K. E. Stiglbauer, and P. L. Ruegg. 2013. Risk factors for clinical mastitis, 
ketosis, and pneumonia in dairy cattle on organic and small conventional farms in the United States. J. Dairy Sci. 96:4269-4285.

Roesch, M., M. G. Doherr, W. Schaeren, M. Schaellibaum, and J. W. Blum. 2007. Subclinical mastitis in dairy cows in Swiss organic and conventional production systems. J. Dairy Res. 74:86-92.

Ruegg, P. L. 2009. Management of mastitis on organic and conventional dairy farms. J. Anim. Sci. 87:43-55.

Ruegg, P. L. 2012. New perspectives in udder health management. Vet. Clin. North Am. Food Anim. Pract. 28:149-163.

Sargeant, J. M., H. M. Scott, K. E. Leslie, M. J. Ireland, and A. Bashiri. 1998. Clinical mastitis in dairy cattle in Ontario: Frequency of occurrence and bacteriological isolates. Can. Vet. J. 39:33-38.

Sato, K., P. C. Bartlett, R. J. Erskine, and J. B. Kaneene. 2005. A comparison of production and management between Wisconsin organic and conventional dairy herds. Livest. Prod. Sci. 93:105-115.

Schukken, Y. H., R. N. Gonzalez, L. L. Tikofsky, H. F. Schulte, C. G. Santisteban, F. L. Welcome, G. J. Bennett, M. J. Zurakowski, and R. N. Zadoks. 2009. CNS mastitis: Nothing to worry about? Vet. Microbiol. 134:9-14.

Schukken, Y. H., F. J. Grommers, D. Vandegeer, H. N. Erb, and A. Brand. 1990. Risk-factors for clinical mastitis in herds with a low bulk milk somatic cell count. 1. Data and risk factors for all cases. J. Dairy Sci. 73:3463-3471.

Schukken, Y. H., J. A. H. Smit, F. J. Grommers, D. Vandegeer, and A. Brand. 1989. Effect of freezing on bacteriologic culturing of mastitis milk samples. J. Dairy Sci. 72:1900-1906.
Siivonen, J., S. Taponen, M. Hovinen, M. Pastell, B. J. Lensink, S. Pyörälä, and L. Hänninen. 2011. Impact of acute clinical mastitis on cow behaviour. Appl. Anim. Behav. Sci. 132:101-106.

Stiglbauer, K. E., K. M. Cicconi-Hogan, R. Richert, Y. H. Schukken, P. L. Ruegg, and M. Gamroth. 2013. Assessment of herd management on organic and conventional dairy farms in the United States. J. Dairy Sci. 96:1290-1300.

Taponen, S., H. Simojoki, M. Haveri, H. D. Larsen, and S. Pyörälä. 2006. Clinical characteristics and persistence of bovine mastitis caused by different species of coagulase-negative staphylococci identified with API or AFLP. Vet. Microbiol. 115:199-207.

Thompson-Crispi, K. A., M. Filippo, and B. A. Mallard. 2013. Incidence rates of clinical mastitis among Canadian Holsteins classified as high, average, or low immune responders. Clin. Vaccine Immunol. 20:106-112.

Vaarst, M., L. Alban, L. Mogensen, S. Milan, Thamsborg, and E. S. Kristensen. 2001. Health and welfare in Danish dairy cattle in the transition to organic production: Problems, priorities and perspectives. J. Agric. Environ. Ethics 14:367-390.

Verbeke, J., S. Piepers, K. Supre, and S. De Vliegher. 2014. Pathogenspecific incidence rate of clinical mastitis in Flemish dairy herds, severity, and association with herd hygiene. J. Dairy Sci. 97:69266934 .

Zorah, K. T., R. C. W. Daniel, and A. J. Frost. 1993. Detection of bacterial-antigens in milk samples from clinical cases of bovine mastitis in which culture is negative. Vet. Rec. 132:208-210. 